for example, to depend in an important way on the numbers which are manufactured. This is where easy access to the larger market of the EEC would be a great benefit to many British industries. In computers, nuclear power and even aircraft, there is obviously a great deal to be gained. One difficulty is that the EEC has not yet made nations more willing to leave prestigious technology to their partners, and. it will be a decade or so before European companies can possibly have grown to the point at which national interests are thoroughly eroded. It follows that if the full potential of the comparatively advanced industries in Britain were to be fully exploited within the EEC, there would have to be some tangible agreements about who does what, at least in the decade immediately ahead.

But there is more to the EEC than the balance of economic advantage. This, quite properly, is something that Mr. Wilson is also saying. What does it imply for the technical community, in Britain and the rest of Europe? Mr. Wilson has in mind not merely the growth of common institutions which are able to influence the course of events, but also the way in which people brought together by common problems do neccssarily find themselves persuading each other to behave differently. British membership of the EEC may well bring extra flexibility, both to the British Government and to the present members of the community, and this, of course, is where the scientific and technical community has the most to offer and the most to gain. At this stage, when there is very little experience to fall back on, it is natural to retell the heroic tale of how CERN has kept high energy physics alive in Europe (and it will be surprising if some at least do not seek to establish the principle that one test of a nation's European sympathies is its willingness to subscribe towards the $300 \mathrm{GeV}$ accelerator). But there are more lasting benefits to be won from less tangible ways of pooling European talents. In the universities, for example, there is at present too great a tendency for the patterns of research to replicate each other, and task sharing would again be a great advantage if it were accompanied by the freedom of people to move freely from one place to another. Still greater benefits could be won from the co-operative use of programmes of basic research. In Europe at present, for example, there are three substantial programmes of research and development from which fast nuclear reactors will eventually emerge. Can all of them be necessary?

And this, of course, is the sense in which Mr. Wilson's concept of the European technological community comes really into its own. British technology, past and present, is undoubtedly something of an asset, but it will only be fully usable if attention is paid urgently to the ways in which industry is enabled to use what has been done. But the most spectacular prizes lie in the future. If there can be found some way of welding the technical community of Europe together in such a way that people move freely to where they can be most useful, and if the people already skilled can be harnessed on a really generous scale to the problems of higher education, the result could surprise even the Common Market zealots. To say that it would take very little sacrifice of any nation's sovereignty to match in Europe the academic work now being done in the United States is a small way of describing the opportunities which do exist. What really matters is that the opportunity is immeasurable. That in itself would justify the British application.

\section{ONE BLIND EYE}

Professor William Shockley, distinguished for his part in the invention of the transistor, appeared at the Annual Meeting of the National Academy of Sciences last month in an unusual role--as something between a geneticist and a social commentator. His declared object was to face facts about "the quantity problem of the world population". His open fear was a generalized version of that old jingle from Mr. Kingsley Amis that "more means worse". He was, for example, depressed to have to point out that children from large families tend to be at a disadvantage in various kinds of competitions. With tactless zeal, he seized on statistics which compare the IQ measurements of negro and white entrants to the armed services in the United States, and pointed out that an apparent disparity between the two populations has apparently increased a little in recent years. All this, said Professor Shockley, is entirely consistent with a view that social capability is entirely determined by genetics and not environment, and his talk was decked out here and there with mention of eugenics. To be sure, Professor Shockley did not suggest that his studies were a proof that heredity is all that matters, but merely that there is an urgent need for a serious study of his hypothesis. Among other things, if "study shows that ghetto birth rates are actually lowering average negro intelligence, objectively facing this fact might lead to finding ways to prevent a form of genetic enslavement that could provoke extremes of racism".

Objectivity is, of course, a virtue, and Professor Shockley was right to insist that nasty social problems are as much in need of detailed study as those where solutions promise to be easy. $\mathrm{He}$ is also entirely at liberty to stray from solid-state physics into sociology -indeed, too many people are too willing to keep themselves in the blinkers which their disciplines impose. But Professor Shockley has not merely been guilty of bad taste in basing an argument on the inheritance of social capabilities almost exclusively on examples drawn from comparisons between negroes and other types. He has also overlooked, knowingly or otherwise, a great wealth of information bearing on the influence of heredity and environment on individual development. Although there are some who will say that Professor Shockley should have stuck to his last, the real lesson is that he should have done his homework much more carefully. 